\title{
PENGARUH KELEMBAPAN RELATIF DAN SUHU TERHADAP AKTIVITAS GLUKOAMILASE ASPERGILLUS FLAVUS PADA PENYAKIT SIMPANAN GAPLEK
}

\author{
H. A. Oramahi ${ }^{1}$, Christanti Sumardiyono ${ }^{2}$, Nursamsi Pusposendjojo ${ }^{2}$, dan Haryadi $^{3}$
}

\begin{abstract}
The effect of relative humidity and temperatur to glucoamylase activity of Aspergillus flavus on storage disease of dried cassava. Aspergillus flavus is the most important species because of its toxigenic caracteristic on agricultural product. Among several Aspergillus species growing on dried cassava. This study was conducted to show the role of glucoamylase produced by Aspergillus flavus fowards the storage disease of dried cassava. The effect of RH and storage room temperature to glucoamylase activity was evaluated for 4 months using Randomized Completely Block Design (Factorial). Variables observed were glucoamylase activity and starch content of dried cassava. Glucoamylase activity could be used as an early indicator of the infestation of dried cassava by Aspergillus while the change of dried cassava color had not been visible. Starch content of dried cassava decreased during the storage. Due to the glucoamylase activity of A. flavus which degrading starch into glucose. The interaction effect of RH and storage room temperature to glucoamylase activity of A. flavus was significant.
\end{abstract}

Key words: storage disease, dried cassava, glucoamylase, Aspergillus flavus

\section{PENDAHULUAN}

Penyakit pascapanen terdiri atas penyakit nonpatogenik dan patogenik, terutama dalam bahan simpanan, yang sering disebut sebagai penyakit simpanan (storage disease) (Semangun, 2001). Jamur merupakan salah satu ancaman terpenting sebagai penyebab kerusakan hasil pertanian yang disimpan atau diolah. Kerusakan tersebut lebih parah terjadi di daerah tropika basah dan hangat yang kondisinya cocok bagi penyebaran dan pertumbuhan jamur tersebut (Essono et al., 2007). Jamur dapat menimbulkan kerusakan melalui proses enzimatis karena jamur dapat mengeluarkan enzim pendegradasi komponen pada bahan simpanan.

Pengujian aktivitas enzim merupakan metode yang cepat dan akurat sebagai indikator kerusakan biji-bijian yang disebabkan oleh jamur. Pengujian enzim sebagai indikator kerusakan bahan tergantung pada substrat yang dominan pada bahan hasil pertanian. Beberapa penelitian sebelumnya mengungkapkan bahwa enzim proteolitik yang dihasilkan oleh Aspergillus dan Penicillium dapat digunakan sebagai indikator kerusakan kacang tanah, sedangkan enzim lipolitik yang dihasilkan oleh Aspergillus dan Penicillium dapat dipakai sebagai indikator kerusakan kopra (Ismail, 2001).
Berdasarkan kenyataan di atas maka diduga kerusakan gaplek akibat jamur Aspergillus dapat dideteksi melalui pengukuran aktivitas glukoamilase. Hal ini disebabkan gaplek mengandung pati yang tinggi sehingga jamur marga Aspergilus yang tumbuh pada gaplek mampu menghasilkan glukoamilase. Aktivitas glukoamilase ini menyebabkan perombakan pati menjadi glukosa. Penurunan kadar pati akibat aktivitas enzim tersebut dapat diduga dengan membandingkan kadar pati gaplek yang ditumbuhi oleh jamur Aspergillus dengan gaplek yang tidak ditumbuhi oleh jamur Aspergillus.

Gaplek merupakan medium yang cocok untuk pertumbuhan dan perkembangan Aspergillus. Jamurjamur yang dilaporkan tumbuh pada gaplek antara lain A. clavatus, A. flavus, A. fumigatus, A. niger, dan A. ochraceus (Yulineri et al., 1997; Wareing et al., 2001; Essono et al., 2007). Di antara spesies-spesies tersebut, A. flavus merupakan jamur toksigenik yang sering ditemukan tumbuh dominan pada produk hasil pertanian. Beberapa pustaka sebelumnya mengungkapkan bahwa kehilangan hasil gaplek dalam simpanan mencapai 16-25\% (Balagopalan et al., 1988; Ginting et al., 1992).

Penelitian yang telah dilakukan dan dipublikasikan juga belum mencakup peran aktivitas glukoamilase yang dihasilkan A. flavus pada penyakit

\footnotetext{
${ }^{1}$ Jurusan Teknologi Hasil Hutan, Fakultas Kehutanan, Universitas Tanjungpura Pontianak, Jl. Imam Bonjol Pontianak 78124.

2 Jurusan Perlindungan Tanaman, Fakultas Pertanian, Universitas Gadjah Mada, Bulaksumur Yogyakarta.

${ }^{3}$ Jurusan Teknologi Pengolahan Hasil Pertanian, Fakultas Teknologi Pertanian, Universitas Gadjah Mada, Bulaksumur Yogyakarta.
} 